\title{
A COMPARATIVE STUDY OF THE USE OF CASSAVA SPECIES AND ALUM IN WASTE WATER TREATMENT
}

\author{
A. Adamu ${ }^{1}$, D.B. Adie², U.A. Alka ${ }^{3}$ \\ 1,2,3 Dept of Water Resources and EnVIRonmental EngineERING, AHMAdu Bello University, Zaria. NiGERIA \\ E-mail addresses. ${ }^{1}$ adamualiyu@abu.edu.ng,2donadie2005@yahoo.com,3alkaumaralka@yahoo.com
}

\begin{abstract}
This research was conducted to study the performance of two varieties of cassava as coagulants in waste water treatment and compare them with alum. Heavy metals composition of the two varieties of cassava used were also studied. The results showed that, the acid treated portion of specie A (Manihot palmate) recorded $51.8 \%$ turbidity reduction efficiency and $70 \%$ reduction in alkalinity; while for the untreated portion of specie $A$ recorded $60 \%$ reduction in alkalinity. The acid treated portion of specie B (Manihot aipi) recorded a $58.3 \%$ reduction in turbidity and $80 \%$ reduction in alkalinity; while the alum reduced the turbidity by $43.7 \%$ at the dosage of 50ml. The untreated portion of specie $B$, showed $80 \%$ reduction in TSS and a $70 \%$ reduction in alkalinity. The heavy metals contents of the two species of cassava were obtained as: $\mathrm{Cu}(0.077 \mu \mathrm{g} / \mathrm{g}), \mathrm{Cd}(0.000 \mu \mathrm{g} / \mathrm{g})$, and $\mathrm{Zn}(0.231 \mu \mathrm{g} / \mathrm{g}), \mathrm{Ni}$ $(0.168 \mu \mathrm{g} / \mathrm{g}), \mathrm{Mn}(8.516 \mu \mathrm{g} / \mathrm{g})$ and $\mathrm{Pb}(0.144 \mu \mathrm{g} / \mathrm{g})$ for specie $\mathrm{A}$ and $\mathrm{Cu}(0.086 \mu \mathrm{g} / \mathrm{g}), \mathrm{Cd}(0.000 \mu \mathrm{g} / \mathrm{g}), \mathrm{Zn}(0.258$ $\mu \mathrm{g} / \mathrm{g}), \mathrm{Mn}(9.624 \mu \mathrm{g} / \mathrm{g})$ and $\mathrm{Pb}(0.047 \mu \mathrm{g} / \mathrm{g})$ for specie B; while the heavy metals contents of the wastewater were: $\mathrm{Cu}(0.036 \mathrm{mg} / \mathrm{I}), \mathrm{Cd}(0.056 \mathrm{mg} / \mathrm{I}), \mathrm{Zn}(0.269 \mathrm{mg} / \mathrm{I}), \mathrm{Ni}(0.000 \mathrm{mg} / \mathrm{I}), \mathrm{Mn}(0.505 \mathrm{mg} / \mathrm{I})$ and $\mathrm{Pb}(0.137 \mathrm{mg} / \mathrm{I})$. It was concluded that the two cassava species were more effective than alum as coagulants in wastewater treatment.
\end{abstract}

Keywords: cassava, coagulants, wastewater, alum, treatment

\section{INTRODUCTION}

Cassava is a dicotyledonous plant belonging to the botanical family Euphorbiaceous [1] and like most members of the family; the cassava plant contains laticifiers and produces latex [2]. It is extensively cultivated as an annual crop in tropical and subtropical regions for its edible starchy, tuberous root and a major source of carbohydrates. The cassava plant is a slightly woody, perennial shrub that grows under cultivation to a height of about $2.4 \mathrm{~m}$ [3].

The plant is propagated from mature stems, which are planted without special treatment. It is originated from North-East Brazil (South America). It is now grown in Indonesia, Malaysia, Philippines, Thailand and parts of Africa including Nigeria that has recently become the world's greatest producer of cassava [4]. It is often seen as a drought-tolerant famine reserve crop and is therefore thought to be ideal for marginal rainfall areas [1]. Cassava grows on most soils but best in light to medium loams which facilitate tuber development and harvesting. Cassava extracts less nitrogen and phosphates than most other crops but has a high demand for potassium and the roots are well developed to take up sulphur and zinc [5].

Cassava can also be classified into short-season cultivars which mature early at 6 months after planting and cannot be left in the ground longer than 9 - 11 months without serious deterioration. These are often sweet cassava. Long-season cultivars which take at least one year or more to mature and some of them may be left in the ground 3 - 4 years without serious deterioration, these tend to be bitter cassava [6]. These numerous varieties of cassava are usually grouped into two main categories: Manihot palmate (bitter cassava) and Manihot aipi (sweet cassava). The bitter cassava is easily recognized first by its green leaf stalk and the whitish outer cortical layer of the root. The sweet cassava has a red leaf stalk with a purplish outer cortical layer [7]. The two cassava species used in this research are: Manihot palmate (specie A) and Manihot aipi (specie B). The specie A is a bitter variety which is common in the southern part of Nigeria. It is characterized by a brownish stem with buds from which leaves spring forth. The leaves have a greenish color when the cassava is growing and turn

* Corresponding author, Tel: +234-8062619284 
yellow when the cassava is ripe and ready for harvesting. This variety cannot be consumed raw unless some form of processing is done. The specie B is a sweet variety which grows in parts of northern Nigeria. It has green leaves which turn reddish-green when the cassava is ripe. The stem is red in colour and the tubers are brown in colour when harvested which when peeled have a darker shade of creamy white color. It can be consumed raw with no form of processing.

The high content of hydrogen cyanide ( $\mathrm{HCN})$ in cassava has been a source of concern for human consumption because of its toxicity. Of particular concern are the cyanogenic glycosides of cassava (linamarin and lotaustralin). These, on hydrolysis, release HCN. The HCN is a gas with a boiling point of $25^{\circ} \mathrm{C}$ that easily dissipates into air at ambient temperature once produced. Different processing methods have been found to reduce the HCN level in cassava. Steeping of cassava in water for an extended period of time ( $2-5$ days) allows submerged fermentation to occur and leads to the breakdown of the cyanogenic glycosides. Grinding and fermentation have been reported to achieve the highest rate of detoxification of cassava food resulting in HCN reduction by over $90 \%$ [8]. Other studies have found that HCN is reduced to $14.2 \%$ by boiling, $11.3 \%$ by baking and $11.3 \%$ by frying, while steaming and drying reduces the HCN level by $15.7 \%$ and $27.5 \%$ respectively [9].

The chemical composition of cassava roots differs considerably. Studies of 30 varieties of cassava in Mexico gave the following results: the dry-matter content of the roots varied between $24 \%$ and $52 \%$, with a medium of $35 \%$; protein content varied between $1 \%$ and $6 \%$, with a medium of $3.5 \%$ [10].

On the other hand, alum is both a specific chemical compound and a class of chemical compound. The specific compound is the hydrated potassium aluminium sulphate (potassium alum) with the formula $\mathrm{KAl}\left(\mathrm{SO}_{4}\right)_{2} \cdot 12 \mathrm{H}_{2} \mathrm{O}$. More widely, alums are double sulphate salts, with the formula $\mathrm{AM}\left(\mathrm{SO}_{4}\right)_{2} \cdot 12 \mathrm{H}_{2} \mathrm{O}$, where $\mathrm{A}$ is a monovalent cation such as potassium or and $\mathrm{M}$ is a trivalent metal ion such as aluminium or chromium (III) [11], but the commercial alum is $\mathrm{Al}_{2} \mathrm{SO}_{4} \cdot 14 \mathrm{H}_{2} \mathrm{O}$ and $1 \mathrm{mg} / \mathrm{l}$ of alum destroys $0.5 \mathrm{mg} / \mathrm{l}$ alkalinity as $\mathrm{CaCO} 3$ and produces $0.44 \mathrm{mg} / \mathrm{l}$ carbon dioxide[12]. The reactions that take place when aluminium sulphate is added to water are complex and are summarised as:
$\mathrm{Al}_{2}(\mathrm{SO} 4)_{3}+3 \mathrm{Ca}(\mathrm{HCO} 3)_{2} \rightarrow 2 \mathrm{Al}(\mathrm{OH})_{3}+3 \mathrm{CaSO}_{4}+6 \mathrm{CO}_{2}$ For many years alum has been the most popular coagulant for water treatment [12], and most treatment plants use alum as their coagulants. There is the need to provide an alternative coagulant in water treatment and compare its effectiveness with alum. The Manihot palmate and Manihot aipi were use in this research in order to study their feasibilities to be used as coagulants and compare their efficiencies with alum since alum has been known to be the commonest coagulant use in the water treatment. Therefore, this research was focus on coagulants comparison.

The objective of this research is to study the performance of two varieties of cassava (Manihot palmate and Manihot aipi) as coagulants in wastewater treatment and compare their performance with alum to determine the more effective coagulant between the cassava and alum which has known to be the conventional coagulant in water treatment. With this, an alternative coagulant can be studied so that it can be use in water treatment. The heavy metals content in the two varieties of cassava was also studied so as to know whether they are within the safe limit recommended by the World health organisation (WHO) and Food and Agriculture Organisation (FAO) [13]. The heavy metals present in the cassava $(\mathrm{Cu}, \mathrm{Cd}, \mathrm{Zn}, \mathrm{Ni}, \mathrm{Mn}$, and $\mathrm{Pb})$ were selected and analysed considering their various effects on human health. The accumulations of these heavy metals in the human body can cause cancer, heart disease, stroke and obesity [14].

\section{MATERIALS AND METHODS}

In order to determine the performance of the two varieties of cassava as coagulant in the treatment of wastewater, some parameters were measured. Table 1 shows the parameters that were measured, the apparatus or equipments used in determining the parameters and the reagents used. The analysis was carried out in the Environmental Health Laboratory, Department of Water Resources and Environmental Engineering, Ahmadu Bello University, Zaria and all the reagents used were obtained in the Environmental health laboratory.

\subsection{Preparation of cassava and acid treatment}

The cassava species were cleaned carefully and allowed for about 5 minutes to dry-up, peeled and sliced thinly before drying. 
Table 1: materials used and the parameters measured

\begin{tabular}{|c|c|c|c|}
\hline $\mathrm{S} / \mathrm{No}$ & Parameters & Apparatus/equipments & Reagents \\
\hline 1 & $\mathrm{pH}$ & pH meter, washing bottle and beakers. & Buffer solutions \\
\hline 2 & Alkalinity & $\begin{array}{l}\text { Measuring cylinders, conical flask, pipettes } \\
\text { and burettes }\end{array}$ & $\begin{array}{l}\text { Phenolphthalein and methyl-orange } \\
\text { indicators }\end{array}$ \\
\hline 3 & Acidity & $\begin{array}{l}\text { Beakers, conical flask, pipette, burette, } \\
\text { funnel and measuring cylinder }\end{array}$ & Phenolphthalein indicator \\
\hline 4 & $\begin{array}{l}\text { Total suspended } \\
\text { solids (TSS) }\end{array}$ & $\begin{array}{l}\text { Filter paper, watch glass, oven, forceps, } \\
\text { weighing balance and measuring cylinders }\end{array}$ & \\
\hline 5 & $\begin{array}{l}\text { Dissolved oxygen } \\
\text { (DO) }\end{array}$ & $\begin{array}{l}\text { Pipette, burette, dissolved oxygen bottle, } \\
\text { conical flask, funnel and measuring } \\
\text { cylinder. }\end{array}$ & $\begin{array}{l}\text { Alkali-iodide-azide, manganous sulphate, } \\
\text { Concentrated } \mathrm{H}_{2} \mathrm{SO}_{4} \text {, starch and sodium } \\
\text { thiosulphate solution }\end{array}$ \\
\hline 6 & $\begin{array}{l}\text { Biochemical } \\
\text { oxygen demand } \\
\text { (BOD) }\end{array}$ & $\begin{array}{l}\text { BOD bottle, pipette, burette, conical flask, } \\
\text { funnel and measuring cylinders }\end{array}$ & $\begin{array}{l}\text { Alkali-iodide-azide, manganous sulphate, } \\
\text { Concentrated } \mathrm{H}_{2} \mathrm{SO}_{4} \text {, starch and sodium } \\
\text { thiosulphate solution }\end{array}$ \\
\hline
\end{tabular}

They were dried in open air for about 72 hours at ambient temperature, milled by means of local mortar and pestle. The flour of each cassava variety was sieved and the fine powder was collected in the pan. It was then divided into two portions. The first portion was treated with acid, while the second portion was left untreated. $200 \mathrm{~g}$ of the cassava was measured into a beaker and dissolved in excess $0.3 \mathrm{M} \mathrm{HNO}_{3}$. The mixture was allowed to stand undisturbed for 24 hours after which it was washed with distilled water until a $\mathrm{pH}$ of 7.1 was attained. It was then filtered, airdried and stored in a plastic container. The wastewater sample used was collected from the effluent pond of the Chemical Leather Research Institute Samaru, Zaria and stored in plastic gallons for analysis.

\subsection{Digestion of Cassava and heavy metals analysis}

$0.5 \mathrm{~g}$ of the ground air-dried sample was weighed and put in a beaker. $2.5 \mathrm{ml}$ of concentrated $\mathrm{HCl}$ solution and $7.5 \mathrm{ml}$ of $\mathrm{HNO}_{3}$ solutions were added. The beaker was taken to the oven and the content was digested slowly at $200^{\circ} \mathrm{C}$ for $30 \mathrm{~min}$, it was then allowed to cool. The digested sample was poured into $25 \mathrm{ml}$ volumetric flask and deionised water was added to make-up to the mark. The content was filtered using a filter paper and distilled water was added to make-up to the mark. The digested sample was analysed for heavy metals using the Fast Sequential Atomic Absorption Spectrophotometer (VARIAN AA240FS model) in an air acetylene flame starting with blanks followed by the samples to determine the metal ions of copper $(\mathrm{Cu})$, zinc $(\mathrm{Zn})$, lead $(\mathrm{Pb})$, manganese $(\mathrm{Mn})$, and cadmium (Cd).
Jar test was used to dose the wastewater. The doses applied to the alum were $0,10,20,30,40$ and $50 \mathrm{ml}$ respectively for the 5 test tubes containing $100 \mathrm{ml}$ of sample each. The magnetic stirrer was operated at $100 \mathrm{rpm}$ for approximately 1 minute immediately after each beaker was dosed. The speed of the stirrer was then reduced to $10 \mathrm{rpm}$, and allowed to stir for 15 minutes. Four sets of 5 beakers containing $100 \mathrm{ml}$ of the wastewater each were prepared. For the acid treated cassava, $50 \mathrm{~g}$ was dissolved in $100 \mathrm{ml}$ of distilled water. The mixture was stirred for $1 \mathrm{~min}$ using the magnetic stirrer and then filtered using filter material. The filtrates were used to dose the first 2 sets of 5 beakers of wastewater using $0,10,20,30,40$ and $50 \mathrm{ml}$ of filtrate respectively. The same procedure was used for the untreated cassava portion. The four sets of dosed wastewater were allowed to stand for $1 \mathrm{hr}$ and then analysed for $\mathrm{pH}$, turbidity, alkalinity, acidity, total suspended solids, dissolved oxygen and biochemical oxygen demand.

\section{RESULTS AND DISCUSSION}

Table 2 indicates the heavy metals contents that were found in the two cassava species which could have originated from the soil in which the cassava species were grown. Specie $\mathrm{A}$ has $\mathrm{Cu}, \mathrm{Zn}, \mathrm{Ni}, \mathrm{Mn}$ and $\mathrm{Pb}$ contents of $0.07,0.231,0.168,8.516$ and $0.144 \mu \mathrm{g} / \mathrm{g}$ respectively; while Specie $\mathrm{B}$ has $\mathrm{Cu}, \mathrm{Zn}, \mathrm{Ni}, \mathrm{Mn}$ and $\mathrm{Pb}$ content of $0.086,0.258,0.189,9.264$ and $0.047 \mu \mathrm{g} / \mathrm{g}$ respectively. It was discovered that specie $B$ has higher heavy metals content than specie A and both of them have no cadmium content. The heavy metals content of manihot palmate and manihot aipianalysed were within the safe limit recommended by WHO/FAO. However, the concentration of the heavy 
metals obtained in this research is lower than that obtained by Adebayo and Rapheal which revealed the concentration of $\mathrm{Cd}, \mathrm{Cu}, \mathrm{Mn}, \mathrm{Ni}, \mathrm{Pb}$ and $\mathrm{Zn}$ in the cassava mash sample dried along highways as: 0.210$0.410 \mu \mathrm{g} / \mathrm{g}, 11.120-18.120 \mu \mathrm{g} / \mathrm{g}, 10.200-17.010 \mu \mathrm{g} / \mathrm{g}$, $0.680-0.920 \mu \mathrm{g} / \mathrm{g}, \quad 0.350-0.660 \mu \mathrm{g} / \mathrm{g}, \quad 9.520-21.330$ $\mu \mathrm{g} / \mathrm{g}$ respectively [15] .The $\mathrm{mg} / \mathrm{l}$ respectively and had no Ni content (Table 2).

Table 3 contains the initial values of the Physicochemical parameters of the wastewater sample. These values served as control for studying the effectiveness of the two varieties of cassava as coagulant in wastewater treatment. The wastewater has initial values of $\mathrm{pH}$, turbidity, acidity, alkalinity, total suspended solids (TSS), dissolved oxygen and biochemical oxygen demand (BOD) of 7.21, 52.3NTU, $20 \mathrm{mg} / \mathrm{l}, 10 \mathrm{mg} / \mathrm{l}, 100 \mathrm{mg} / \mathrm{l}, 1.8 \mathrm{mg} / \mathrm{l}$ and $1.2 \mathrm{mg} / \mathrm{l}$ respectively. These values were used as control for comparing the removal efficiencies of the two cassava species

Both acids treated and untreated species $\mathrm{A}$ and $\mathrm{B}$ showed a rise in $\mathrm{pH}$ from an initial value of 7.21 signifying that the two cassava species made the sample to be more alkaline. But with alum, both species $\mathrm{A}$ and $\mathrm{B}$ encountered a reduction in $\mathrm{pH}$ as alum has been known to destroy alkalinity [12] as shown in Table 4 . In terms of turbidity removal efficiency, both species A and B were more effective than alum in removing the turbidity of the wastewater. The Acid treated portion of specie A recorded the highest turbidity removal efficiency of $51.8 \%$ and $70 \%$ increase in alkalinity at the dosages of $30 \mathrm{ml}$ and $50 \mathrm{ml}$ respectively; while alum reduces the turbidity by $43.7 \%$ at the dosage of $50 \mathrm{ml}$ as presented in Table 5. On the other hand, the acid treated portion of specie B has the highest turbidity removal efficiency of $58.3 \%$ at the dosage of $10 \mathrm{ml}$. There are two possible mechanisms that the made coagulants to caused the removal of turbidity in the wastewater. The first one first one involves the neutralization of the surface charge on the particle so that they can adhere to each other forming particles large enough to settle by gravity in a reasonable time. The second mechanism is that the coagulants added form a precipitate which settles by gravity in a reasonable time. Additionally, adsorption and layer compression can also occur during coagulation [16]. The chemical changes that enhanced the coagulating abilities of acid treated cassava species is possibly due to the fact that the coagulation process is depended on $\mathrm{pH}$ and treating the cassava with acid provides lower
$\mathrm{pH}$ that improves the coagulating abilities of the cassava species [17].

Similarly, study has shown that Moringa Oleifera seeds extract can also remove turbidity of water [18]. It has been found that $320 \mathrm{mg} / \mathrm{l}$ of the extract dosage can remove the turbidity of water by $58.9 \%$, while $480 \mathrm{mg} / \mathrm{l}, \quad 640 \mathrm{mg} / \mathrm{l}$ and $800 \mathrm{mg} / \mathrm{l}$ can remove the turbidity of water by $74.8 \%, 81.9 \%$ and $84.0 \%$ respectively [18].

However, both the acid treated and untreated for specie A and B caused an increase in acidity of the sample from initial value of $20 \mathrm{mg} / \mathrm{l}$ at all dosages as shown in Table 6. Similarly, the acid treated specie A recorded a rise in alkalinity from a control value of $10 \mathrm{mg} / \mathrm{l}$, but acid treated of specie $B$ and acid untreated of species A and B caused a decline in alkalinity (Table 7).

Table 2: Heavy metals content of wastewater and species

\begin{tabular}{lcccccc}
\multicolumn{7}{c}{$A$ and $B$} \\
\hline Heavy metal & $\mathrm{Cu}$ & $\mathrm{Cd}$ & $\mathrm{Zn}$ & $\mathrm{Ni}$ & $\mathrm{Mn}$ & $\mathrm{Pb}$ \\
\hline $\begin{array}{l}\text { Wastewater } \\
(\mathrm{mg} / \mathrm{l})\end{array}$ & 0.036 & 0.056 & 0.269 & 0.000 & 0.505 & 0.137 \\
$\begin{array}{l}\text { Specie A } \\
(\mu \mathrm{g} / \mathrm{g})\end{array}$ & 0.077 & 0.000 & 0.231 & 0.168 & 8.516 & 0.144 \\
$\begin{array}{l}\text { Specie } \\
\mathrm{B}(\mu \mathrm{g} / \mathrm{g})\end{array}$ & 0.086 & 0.000 & 0.258 & 0.189 & 9.264 & 0.047 \\
\hline
\end{tabular}

Table 3: Initial values (control) of the Physico- chemical

\begin{tabular}{ll}
\multicolumn{2}{c}{ parameters in the wastewater } \\
\hline Parameter & Initial Value \\
\hline pH & 7.21 \\
Turbidity (NTU) & 52.3 \\
Acidity (mg/l) & 20 \\
Alkalinity (mg/l) & 10 \\
TSS (mg/l) & 100 \\
DO (mg/l) & 1.8 \\
BOD (mg/l) & 1.2 \\
\hline
\end{tabular}

Table 4: $p H$ values of the wastewater at various dosages of coagulants

\begin{tabular}{cccccc}
\hline $\begin{array}{c}\text { Dosage } \\
\text { ml }\end{array}$ & Alum & $\begin{array}{c}\text { Acid } \\
\text { treated } \\
\text { A }\end{array}$ & $\begin{array}{c}\text { Untreated } \\
\text { A }\end{array}$ & $\begin{array}{c}\text { Acid } \\
\text { treated } \\
\text { B }\end{array}$ & $\begin{array}{c}\text { Untreated } \\
\text { B }\end{array}$ \\
\hline 0 & 7.21 & 7.21 & 7.21 & 7.21 & 7.21 \\
10 & 7.19 & 7.37 & 8.18 & 7.55 & 7.82 \\
20 & 6.98 & 7.36 & 7.96 & 7.64 & 7.69 \\
30 & 6.96 & 7.39 & 7.98 & 7.39 & 7.70 \\
40 & 6.83 & 7.38 & 7.03 & 7.34 & 7.92 \\
50 & 6.49 & 7.39 & 7.44 & 7.52 & 7.87 \\
\hline
\end{tabular}

Table 5: Turbidity (NTU) values of the wastewater at various dosages of coagulants

\begin{tabular}{cccc}
\multicolumn{4}{c}{ various dosages of coagulants } \\
\hline Dosage ml & Alum & Acid treated A & Acid treated B \\
\hline 0 & 52.3 & 52.3 & 52.3 \\
10 & 32.4 & 27.6 & 21.8 \\
20 & 30.0 & 27.5 & 21.9 \\
30 & 74.0 & 25.2 & 26.4 \\
40 & 89.0 & 28.2 & 40.7 \\
50 & 29.4 & 27.9 & 28.2 \\
\hline
\end{tabular}


Table 6: Acidity (mg/l) values of the wastewater at various dosages of coagulants

\begin{tabular}{ccccc}
\hline $\begin{array}{c}\text { Dosage } \\
\text { ml }\end{array}$ & $\begin{array}{c}\text { Acid } \\
\text { treated A }\end{array}$ & $\begin{array}{c}\text { Untreated } \\
\text { A }\end{array}$ & $\begin{array}{c}\text { Acid } \\
\text { treated B }\end{array}$ & $\begin{array}{c}\text { Untreated } \\
\text { B }\end{array}$ \\
\hline 0 & 20 & 20 & 20 & 20 \\
10 & 40 & 30 & 20 & 45 \\
20 & 35 & 90 & 20 & 30 \\
30 & 35 & 75 & 25 & 35 \\
40 & 30 & 20 & 25 & 90 \\
50 & 33 & 25 & 21 & 85 \\
\hline
\end{tabular}

Table 7: Alkalinity ( $\mathrm{mg} / \mathrm{l})$ values of wastewater at various dosages of coagulants

\begin{tabular}{ccccc}
\hline $\begin{array}{c}\text { Dosage } \\
\text { ml }\end{array}$ & $\begin{array}{c}\text { Acid } \\
\text { treated A }\end{array}$ & $\begin{array}{c}\text { Untreated } \\
\text { A }\end{array}$ & $\begin{array}{c}\text { Acid } \\
\text { treated B }\end{array}$ & $\begin{array}{c}\text { Untreated } \\
\text { B }\end{array}$ \\
\hline 0 & 10 & 10 & 10 & 10 \\
10 & 15 & 7 & 2 & 3 \\
20 & 3 & 8 & 8 & 5 \\
30 & 14 & 8 & 9 & 5 \\
40 & 25 & 8 & 7 & 8 \\
50 & 17 & 4 & 5 & 9 \\
\hline
\end{tabular}

In terms of the Total suspended solids (TSS), untreated specie A showed a rise in TSS at all the dosages applied; while untreated B showed a decrease in TSS except at dosage of $50 \mathrm{ml}$. This is to say that specie A is not as effective as specie B in terms of TSS removal (Figure 1). Similarly, there was rise in the dissolved oxygen content when the untreated specie B and $A$ were applied to the wastewater for all dosages compared to the alum (Figure 2). Nevertheless, both untreated species A and B caused increase in BOD of the sample from the initial value of $1.2 \mathrm{mg} / \mathrm{l}$. This could be due to the fact that cassava is an organic compound, which tends to increase the organic content of the wastewater thereby causing a rise in the BOD. At all the dosages of cassava species A and B, the BOD was higher than the control value of $1.2 \mathrm{mg} / \mathrm{l}$ (Figure 3).

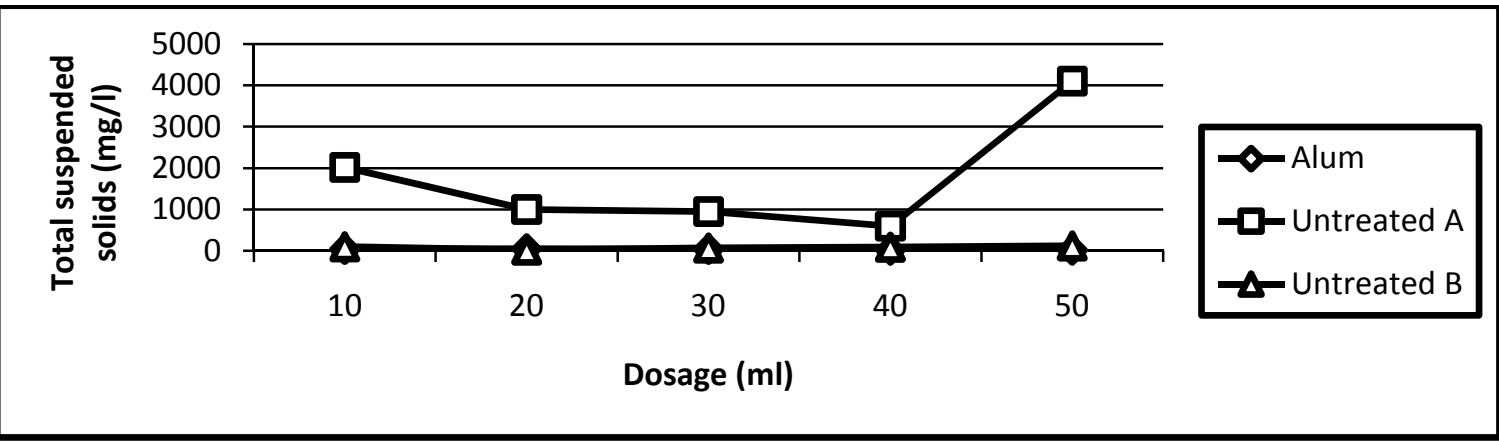

Fig. 1: Variation Total suspended solids with dosages

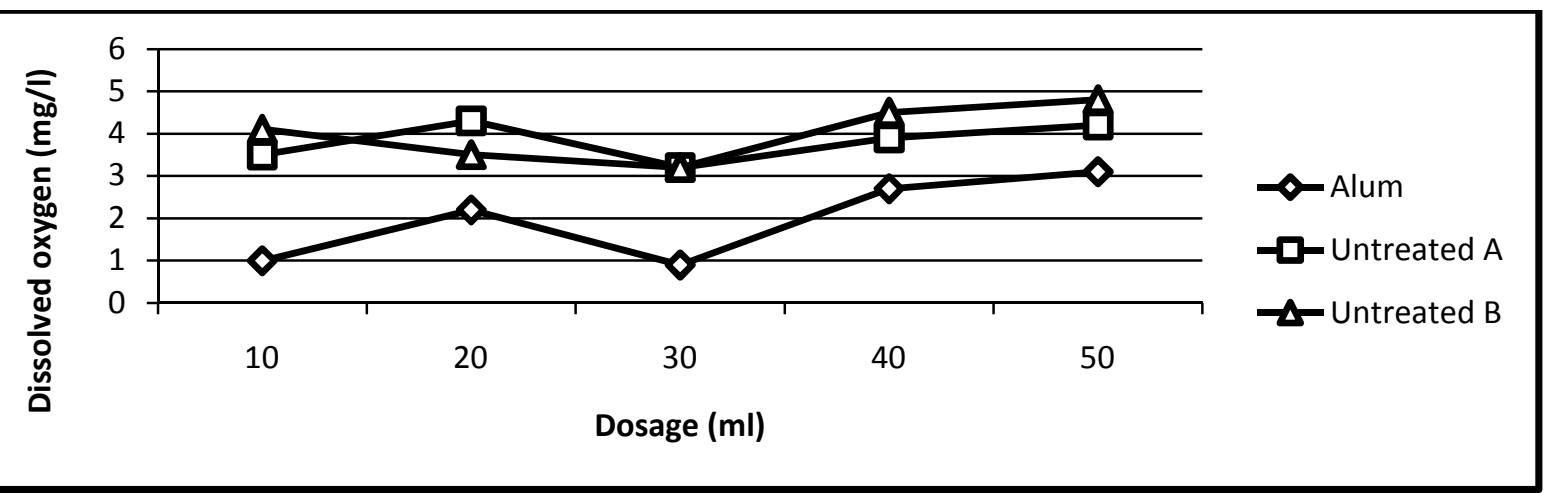

Fig. 2: Variation in dissolved oxygen with dosages

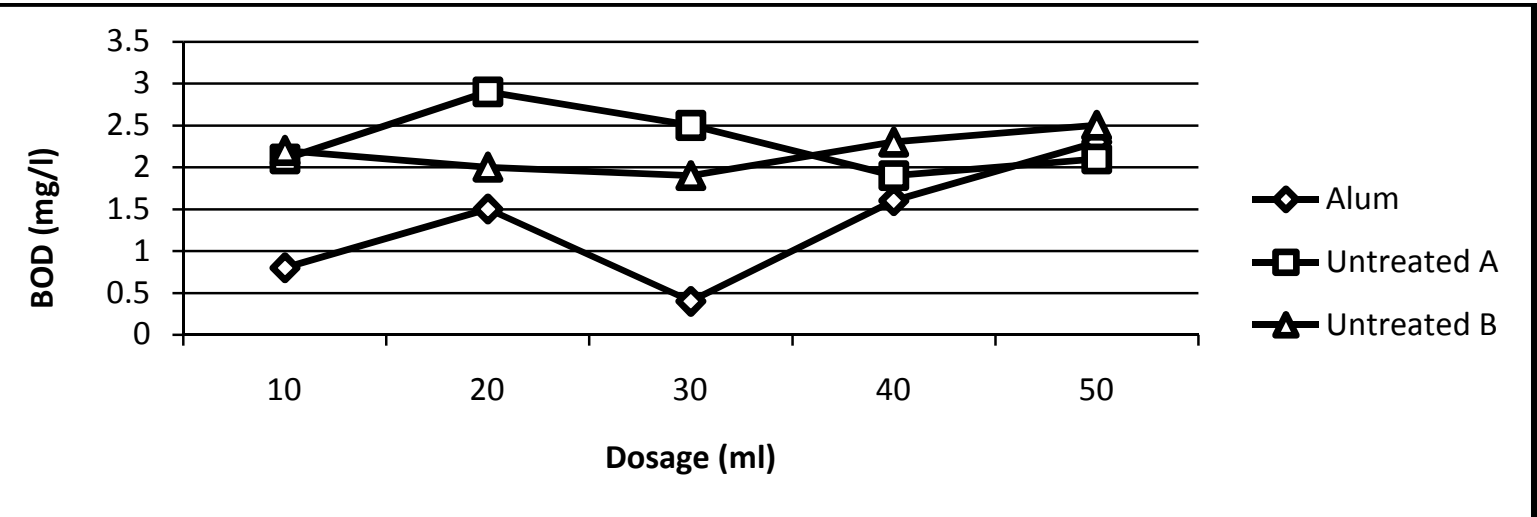

Fig. 3: Variations in BOD with dosages 


\section{CONCLUSION}

Based on the experimental work carried out, it can be concluded that the two varieties of cassava (Manihot palmate and Manihot aipi) can be used as coagulants in wastewater treatment. However, treating the cassava with acid enhanced its ability to be used as a coagulant. The acid treated portion of specie A recorded the highest turbidity removal efficiency of $51.8 \%$ and $70 \%$ increase in alkalinity at the dosages of at the dosage of $30 \mathrm{ml}$ and $50 \mathrm{ml}$ respectively; while alum reduces the turbidity by $43.7 \%$ at the dosage of $50 \mathrm{ml}$. On the other hand, the acid treated portion of specie $B$ has the highest turbidity removal efficiency of $58.3 \%$ at the dosage of $10 \mathrm{ml}$, implying that the two cassava species were more efficient than alum as coagulants in wastewater treatment. The application of the two varieties of cassava caused a rise in BOD of the wastewater implying that the cassava tends to increase the organic contents of the wastewater. The levels of heavy metals contained in the two cassava species were within the acceptable safe limits set by the WHO/FAO (2007).

\section{REFERENCES}

[1] Schulthness F., Chabi-Olaye, A. and Gounou, S. "Multitrophic levels interactions in a cassava-maize mixed cropping system in the humid tropics of West Africa", Bulletin of Entomology Resources, vol. 94, 2004, pp 261-272.

[2] Weber E.J., Cock, J.H. and Chouinard, A. "Cassava harvesting and processing", Proceedings of a Workshop Held at CIAT, April 24-28, 1978, California

[3] Oboh, G. and Elusiyan, C.A. "Changes in the nutrient and anti nutrient content of Micro-fungi fermented cassava flour produced from low and mediumcyanide variety cassava tubers", African Journal of Biotechnology, vol. 6, 2007, pp 2150-2157.

[4] Leotard G., Duputie, A. Graville, J. Douzery, E. Debain, C. and McKey, D. "Phylogeography and the origin of cassava", New insights from the northern rim of the Amazonian basin, Mol. Phylogenet. Evol. Vol. 53, 2009, 329-334.
[5] Rasper, V. and Coursey, D.G. "Properties of starches of some West African yams". Journal of Science Food Agriculture, vol. 18, 1967, pp 240-244.

[6] Purseglove J.W. "Tropical crops dictionary" Longman London, 1967

[7] Anazonwu-bello, J.N. "Cassava products and recipes", Ministry of Agriculture, Anambra State, 1977

[8] Kent, J. Detoxification of Cassava Regal Handbook of Industrial Chemistry, Van Nostrand and Co., New York, 1980

[9] Othmer, K. Encyclopedia of Chemical Technology, 3rd edition, John Wiley and Sons, New York, 1978

[10] FAO. "Food and Agricultural Organization of the World Health Organization", Agricultural Services Bulletin Number 8, 1971

[11] Wikipedia "Alum", http:// en.wikipedia.org/wiki, 2014

[12] Tebbutt, T.H.Y “Principles of Water Quality Control, 5th edition, Butter worth - Heinemann, 1998

[13] WHO/FAO "Food Standard and Programme Codex Alimentarius Commission", Joint WHO/FAO, 13th edition, 2007

[14] Igbozuruike, C. I., Opara- Nadi, A. O. and Okere I. K. “ Concentrations of Heavy Metal in the Soil and Cassava Plant on Sewage Sludge Dump, Imo State University, Imo State-Nigeria, 2013

[15] Adebayo, K. S and Rapheal, 0 " Survey of Heavy metal contaminations of Cassava mash and Maize corns dried along highways in some selected States in Northern part of Nigeria", Journal of Advances in Applied Science Research, Vol. 2(5), 2011, pp561-571

[16] Peavy, H. S., Rome, D. R. and Tchobanoglous, G. Environmental Engineering, international Edition, McGraw-Hill, inc, 1985

[17] Pernitsky, D. J. "Coagulation 101", associated Engineering, Calgary, Alberta

[18] Saulawa, S. B. " Stability studies of Moringa Oleifera seed aqueous extracts for use in Water Treatment in Rural Areas, MSc Thesis, Department of Water Resources and Environmental Engineering, Ahmadu Bello University, Zaria, 2010 